\title{
Teaching Practicum: \\ The impacts on classroom management skills of novice lecturers
}

\author{
Pham Thi Thuy Linh ${ }^{1 *}$, Nguyen Van Thang ${ }^{1}$, Ho Tuong Thanh ${ }^{1}$, \\ Hoang Thi Minh Nguyet ${ }^{1}$, Pham Viet Phuong Thao ${ }^{1}$ \\ ${ }^{1}$ University of Language \& International Studies, Vietnam National University, Hanoi, Vietnam \\ *Corresponding author: linh.thithuypham12@gmail.com
}

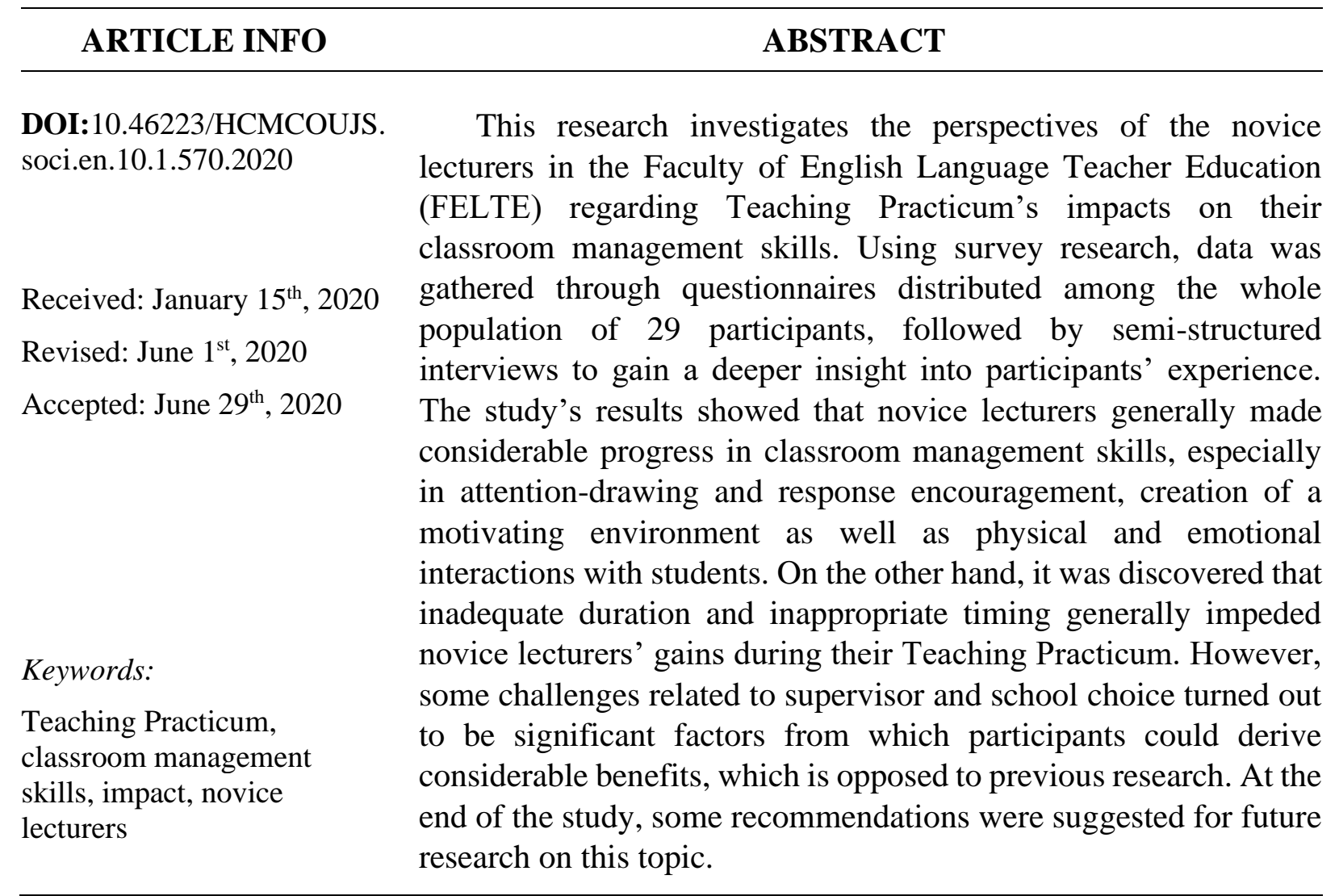

\section{Introduction}

Teaching Practicum is a compulsory part of the learning course for all pedagogical students in the university. This practice aims to "(1) acknowledge the inseparable link between studying and practicing; (2) familiarize students with the authentic teaching environment to nurture their career commitment; (3) enable students to put theory into practice; and (4) be a criterion for graduation assessment" (University of Languages and International Studies, Vietnam National University, Hanoi, 2013, p. 1).

However, there are certain differences among novice teachers' ability to manage real classes after Teaching Practicum. Many studies have found that novice teachers can handle classes more effectively in terms of instruction, communication, discipline, timing, or activity organization (Dicke, Elling, Schmeck, \& Leutner, 2015; Richards \& Farrell, 2013; Scott, Roberta, \& Melissa, 2014; Wagenaar, 2005). Particularly, Teaching Practicum enhanced novice teachers' confidence and efficacy in applying measures to deal with disruptive behavior (O'Neill \& Stephenson, 2012). Meanwhile, many other neophytes are ill-prepared to take full charge, leading to unsatisfactory teaching efficacy (O’Neill \& Stephenson, 2012; Richards \& Farrell, 2013; Scott et al., 2014). Scott et al. (2014) posited that "this practice has been criticized for not sufficiently 
preparing pre-service teachers to cope with full-time teaching" (p. 2). Moreover, a report by Hanoi University of Education pointed out several weaknesses such as communication, in-class problem handling, or time management among novice teachers (Khuc \& Le, 2015). These existing discrepancies raise some questions as to why after undergoing Teaching Practicum program, novice teachers' abilities to handle classes are so diverging.

Given their significance in education, the correlation between Teaching Practicum and classroom management has been a popular subject of investigation. Nevertheless, in many studies, classroom management just constituted a part rather than an exclusive research area (Ozdemir \& Yildirim, 2012; Rahman, Jumani, Akhter, Chisthi, \& Ajmal, 2011; Richards \& Farrell, 2013). Furthermore, Brenes-Carvajal (2009) discovered, "the extent of research on the practicum in the field of language teaching is relatively limited" (p. 34) compared with many other subjects and levels (Andabai, 2013; Hobson, 2006; Rahman et al., 2011).

Given such gaps in existing research, this paper aims at examining the perceived benefits of Teaching Practicum on classroom management skills of novice lecturers in FELTE and the difficulties they encountered during their Practicum. Although the study was carried out in the context of one university, the researchers hope that its results could provide a summary of potential gains in classroom management skills thanks to Teaching Practicum; and keep the student teachers informed of some imminent difficulties during their Practicum.

\section{Literature review}

\subsection{Benefits that novice teachers gain from Teaching Practicum}

It emerged from previous findings that Teaching Practicum serves as a valuable opportunity for student teachers to apply theoretical knowledge into real-life situations (Ngidi \& Sibaya, 2003; Richards \& Farrell, 2013). According to Andabai (2013) and Brenes-Carvajal (2009), Teaching Practicum is aimed to be "a testing ground" for student teachers' understanding and application of their knowledge (Richards \& Farrell, 2013, p. 11). Teaching Practicum also enables teacher trainees to gain empirical experience. A large body of research proved that they stood the chance to learn the art of teaching in an authentic environment (Ngidi \& Sibaya, 2003). In a study by Noonis and Jernice (as cited in Scott et al., 2014), 91\% of teacher trainees confirmed that they gained the requisite hands-on experience to develop a deeper understanding of their students and methods.

Furthermore, Teaching Practicum assists teacher trainees in mental preparation. Some studies confirmed that this practice has specific impacts on student teachers' social-emotional development (Caires, Almeida, \& Vieira, 2012). They confirmed that neophytes initially felt nervousness but there would be a significant improvement in their emotional health after the process of working with students regularly during Teaching Practicum. Another benefit is the sense of belonging to the teacher community. According to Beck and Kosnick (2000), a feeling of belonging majorly depended on the support, acceptance, and acknowledgment from other colleagues. During this practice, many pre-service teachers were aware of the "reasonable levels of acceptance and recognition amongst the school community" (Caires et al., 2012, p. 163). Indeed, "they felt more like a teacher after they started the Practicum" (Genç, 2016, p. 4) and no longer regarded themselves as "an outsider in this profession" (Richards \& Farrell, 2013, p. 17).

Existing research also recognized that Teaching Practicum improves student teachers' selfefficacy regarding classroom management, which will in turn positively influence their skills. According to Sivri and Balci (2015), self-efficacy beliefs are effectively enhanced thanks to the exposure to effective management techniques during Teaching Practice. Empirical studies also 
proved that self-efficacy is closely linked to effective classroom management, as stated by Tschannen-Moran, Hoy, and Hoy (1998). As a result, Teaching Practicum serves as a vital platform as student teachers' self-beliefs will have a considerable impact on their managing classes.

Last but not least, Teaching Practicum facilitates the modification of career perceptions. Given student teachers' first-hand teaching experience, Practicum plays an important role in formulating and modifying the full image of the teaching profession, including the understanding of a teacher's roles and responsibilities and further reflection on their career choice (Scott et al., 2014).

\subsection{Problems related to Teaching Practicum}

During Teaching Practicum, teacher trainees sometimes experienced "shock of reality" the difficult transition from theory to actual teaching (Wagenaar, 2005, p. 1). This was due to the considerable discrepancy between theories and actual teaching (Dicke, Elling, Schmeck, \& Leutner, 2015), which is an obstacle to effective teaching.

In addition, according to Caires et al. (2012) and Hobson (2006), supervisors are crucial facilitators and support providers in student teachers' transition to official teaching. However, in Teaching Practicum, students often encountered problems with their coordinating teachers, especially in terms of inadequate communication and insufficient feedback (Genç, 2016; Ozdemir \& Yildirim, 2012; Sulistiyo, Mukminin, Abdurrahman, \& Haryanto, 2017).

Another problem is the duration and timing of Teaching Practicum. Many studies raised the concern about 6-weeks duration, which may be inadequate for experience acquisition and reflection (Genç, 2016; Sulistiyo et al., 2017). Similarly, Teaching Practicum's frequency is unsatisfactory. According to T. T. Nguyen, Nguyen, and Do (2009) and Sulistiyo et al. (2017), unless Teaching Practicum was conducted several times, student teachers could not constantly revise the theory and method to improve on their performance.

The fourth problem discussed by many studies stems from teacher trainees' insufficient preparation. Specifically, their underestimation of the difficulties in managing classes eventually leads to imbalanced attention between class control and teaching among teacher trainees (Kagan, 1992; Jensen, Sandoval-Hernández, Knoll, \& Gonzalez, 2012; N. T. Nguyen, 2010). According to Jensen et al. (2012), this results in significant reductions in opportunities for effective teaching.

The last problem is the choice of school to practice. Sulistiyo et al. (2017) found that the selection was assigned by higher-ranking organizations, potentially leading to an undesirable quality of partner school. Furthermore, some students encountered problems in choosing suitable schools because of disparities between two educational levels in terms of students and the environment. Another research by Ralph et al. (2007) cited feelings of being "isolated and abandoned" in their practicing school as well as "site-based interpersonal concerns" because they cannot socialize with colleagues in practicing schools (p. 10).

As illustrated above, all research mentioned the influence of Teaching Practicum on the professional development of teachers in both positive and negative terms. Nevertheless, Teaching Practicum's impacts on classroom management skills in English teaching at the tertiary level is not the exclusive area of investigation. Such a gap hence fostered our interest in investigating the impacts of Teaching Practicum on classroom management skills of novice lecturers in FELTE. 


\section{Methodology}

\subsection{Participants}

Our study's population is novice lecturers in the Faculty of English Language Teacher Education (FELTE), ULIS. "Novice lecturers" in our research refers to those who have less than 2 years of official teaching experience in a school or university. We resolved to choose novice lectures for the following reasons. Firstly, they have just undergone Teaching Practicum and accordingly are likely to be most influenced by its impacts. Given their transition into a new environment, they also have the chance to apply skills acquired during Teaching Practicum to their official teaching. Also, according to Ralph (1994), classroom management "seemed to be the most significant element of effective teaching for novice teachers" (p. 189) and Jensen et al. (2012) even found that $25.3 \%$ of novice teachers reported having high "professional development needs" in classroom management (p. 78). The evidence proves that for these neophytes, classroom management is a significant area for improvement. Furthermore, this population also afforded better availability of responses and convenience of contact.

After sending a request to the whole population of 29 lecturers, we received participation confirmation of 17 lecturers (approximately 59\%). Most of the participants had less than one year of experience (10 lecturers) while those with one to two years of experience were seven. Regarding the school choice for Teaching Practicum, 8 lecturers practiced in FELTE while the figures for another university and high school are 4 and 5 lecturers respectively. Among these questionnaire respondents, 9 lecturers consented to take part in a later interview.

\subsection{Instrumentation}

In our research, both questionnaire and semi-structured interview were employed to gather background and in-depth information.

The use of questionnaire enabled us to glean essential and quantifiable information in a short period of time, thus facilitating data generalization. Furthermore, the questionnaire can supplement other data-gathering instruments (Griffee, 2012). Specifically, the questionnaire provided the basis on which we could formulate interview questions pertinent to individual respondents. We decided to utilize well-established questionnaires by Rahman et al. (2011) and Ozdemir and Yildirim (2012) but with pertinent adaptations. While the questionnaire from the former researcher contains 30 items investigating the impacts of teacher training with regards to several aspects such as teaching quality, students' characteristics, classroom management, and human relationship; that from the latter researcher is a combination of three open-ended questionnaires on the effectiveness level of supervisors, the behaviors of teacher trainees during Teaching Practicum and the common problems encountered.

Based on the two questionnaires, we designed our questionnaire in English with three main parts. The first half aims to gather basic information about participants. The second half consists of 26 closed-ended items on Likert scale, ranging from Strongly Disagree (1) to Strongly Agree (5). This part focuses on 2 main aspects, which are: (1) classroom management skills acquired after Teaching Practicum and (2) difficulties during this period. The last part comprises three openended questions asking for further elaboration, other benefits/problems, and interview participation requests.

The interview was our main instrument. Semi-structured interview afforded us the opportunities for "asking, probing and personalization of answers" which could clear up any potential misunderstanding (Wagenaar, 2005, p. 27) and can "reflect inconsistencies and 
contradictions" among responses (Burman \& Parker, as cited in Griffin, 2004, p. 6). Lastly, this method facilitated windows into respondents' emotional world via intonations and non-verbal languages.

The fixed set of interview questions consists of 6 items seeking answers for (1) classroom management skills acquired from Teaching Practicum; (2) a particular case of applying classroom management skills from Teaching Practicum; (3) difficulties related to classroom management; (4) techniques to deal with such difficulties; (5) these techniques' level of applicability in the current situation; and (6) problems encountered during Teaching Practicum.

\subsection{Ethical considerations}

To ensure participants' anonymity, their names in this research have been changed using pseudonyms. Participants were also assured of their voluntary participation. Furthermore, all the videos or tapes will be treated with strict confidentiality and used for research purposes only.

\subsection{Data collection procedure}

Before the actual launch, both questionnaire and interview were pilot tested to ensure correct interpretation by respondents. Three pilot participants were novice lecturers in FELTE and the testing conditions, i.e., time and place, were similar to the official survey. Results of the pilot test identified items that were unclear and irrelevant, which resulted in the removal and modification of several items in the questionnaire and interview question set.

After finalization, the questionnaire was both sent online and in paper form. The gleaned information was then compiled. Among 17 lecturers responding to our questionnaire, 9 consented to partake in the interview, which then took place at ULIS and were conducted in either Vietnamese or English depending on participants' preferences. All the interviews were video or voice recorded with participants' consent for further content analysis. The names of the teachers are pseudonyms.

\subsection{Data analysis procedure}

For quantitative data, demographic information (i.e., age and gender) and years of experience of the participants were first recorded. Then, 26 Likert-scale items were analyzed and reported mode and mean values. Based on this, we could pinpoint the most salient benefits or problems related to Teaching Practicum.

As qualitative data was our main source, it required careful analysis. During this process, we analyzed both the scripts and other factors such as non-verbal languages to further corroborate responses' analysis. There were five main analyzing steps in the qualitative data analysis procedure. Firstly, all the interview recordings were transcribed (and translated into English if necessary). We then read individual transcripts to note overall ideas and significant points. Subsequently, associations with other transcripts and references to other factors were attempted. For each transcript, notes were analyzed to identify recurring themes which were then coded into a short word or phrase. These themes were then listed on a separate paper including transcript instances. Finally, careful revision took place, resulting in 10 recurring themes.

\section{Findings and discussion}

\subsection{Benefits that novice lecturers gained from Teaching Practicum}

It is important to note that all respondents benefited from Teaching Practicum in at least one aspect. This is first illustrated in mean values ranging from 3.24 to 4.06 and mode ranging from 3 (neutral) to 4 (agree). 


\section{Table 1}

Benefits of Teaching Practicum

\begin{tabular}{|l|c|c|}
\hline Benefits from Teaching Practicum & Mean & Mode \\
\hline Better time management & 3.53 & 3 \\
\hline Improved instructional skills & 3.59 & 4 \\
\hline Encouragement of students' participation & 4 & 4 \\
\hline Effective measures to deal with behavioral problems & 3.35 & 3 \\
\hline $\begin{array}{l}\text { Maturity and calmness in reacting to unexpected student } \\
\text { behavior }\end{array}$ & 4 & 4 \\
\hline Rule establishment and adjustment & 3.88 & 4 \\
\hline Implementation of stimulating rewards & 3.88 & 3 \\
\hline Implementation of reactive punishments & 3.24 & 3 \\
\hline Creation of a supportive and stimulating environment & 4 & 4 \\
\hline Encouragement of students' on-task behavior & 4.06 & 4 \\
\hline
\end{tabular}

Source: The researcher's data analysis

One of the most noticeable improvements acknowledged by many novice lecturers is time management, which is evidenced by the mean value at 3.5 in the questionnaire data.

\section{Table 2}

Better Time Management

\begin{tabular}{|c|c|c|}
\hline Benefits from Teaching Practicum & Mean & Mode \\
Better Time Management & 3,5 & 3 \\
\hline
\end{tabular}

Source: The researcher's data analysis

They agreed that this skill was improved when they had to "anticipate all the possible time elongation" to organize a suitable number of activities during Teaching Practicum. Thanks to the empirical experience from Practicum, many teachers learned to estimate time for planned and spontaneous parts, thus better-balancing class time, which upholds other research' results (Dicke et al., 2015; Ralph, 1994).

Improved discipline establishment is another skill attributed to Practice Teaching, which accords with the findings of numerous studies in the current body of research (Andabai, 2013; Caires et al., 2012; Richard \& Farrell, 2013). Particularly, Ms. Mai learned to establish rules in the first lesson. She also mentioned "improvisation" to deal with unexpected cases such as late submission, which bore considerable resemblance to Ms. Linh's case. Having worked with primary students, Ms. Ngoc had to "reiterate all the rules before the lessons" and she greatly benefited from this by her account because this helped university students bear regulations in mind. Meanwhile, the needs analysis was the first step for Ms. Quynh Anh to set rules. In the first lesson, 
she had to make both sides' expectations clear and negotiated class policy, which was further cemented during Practicum.

Another aspect that was agreed by more than half of the interviewees was the improvement in physical and emotional interaction with students. They regarded conversation with students to be a significant improvement as they realized the necessity of effective talks. After the practicum, many teachers "could learn how to freely move around the classroom" and gradually began to "talk to individual students". Specifically, Ms. Phuong realized during Teaching Practicum that students needed a "less distant teacher", so she tried to talk to them during break or after class and it "still works now". The emotional consultation with students that teachers developed during Practicum built their emotional attachment. Accordingly, in the process of working with students, teacher trainees gradually develop their interaction with them, which echoes findings by Andabai (2013) and Richard and Farrell (2013).

One of the most salient benefits discovered by our study is "Attention drawing and response encouragement". In the questionnaire, both "Encouragement of students' on-task behavior" and "Encouragement of students' on-task behavior" are the most highlighted benefits illuminated by the mode and mean values at 4 . Such highest rankings denote unanimous agreement among novice lecturers about this benefit, which is following Ralph's finding (1994).

\section{Table 3}

Attention Drawing and Response Encouragement

\begin{tabular}{|l|c|c|}
\hline \multicolumn{1}{|c|}{ Benefits from teaching practicum } & Mean & Mode \\
\hline Encouragement of students' participation & 4 & 4 \\
\hline Encouragement of students' on-task behavior & 4.06 & 4 \\
\hline
\end{tabular}

Source: The researcher's data analysis

This benefit was also a recurring theme from the interviews. According to Andabai (2013), student inattentiveness and unresponsiveness were regarded as a challenge for novice teachers. However, data from interviews suggested that Practice Teaching helped them to implement proper approaches to handle such challenges. Specifically, incorporating games and activities was the most popular method used by most participants to encourage students' attention and responsiveness. Random asking was another method preferred by Ms. Thao to "elicit answers from students". "Eye contact with inattentive students" was also very effective and sometimes Ms. Ngoc would make sounds or even remain silent to attract their attention. She said that these techniques gained from Teaching Practicum are effective until now. Individual attention to each student to identify their individual needs and find level-relevant activities that engage attention was also mentioned as the course book was rather boring. Indeed, these challenges offered them the chance to find appropriate solutions to attract and sustain attention from students.

Furthermore, one noticeable theme that some lecturers emphasized was "Creation of a Motivating Environment", in which both mean, and mode of this item was 4, indicating an agreeing sentiment among teachers. 


\section{Table 4}

Creation of a Motivating Environment

\begin{tabular}{|c|c|c|}
\hline Benefits from Teaching Practicum & Mean & Mode \\
\hline Creation of a supportive and stimulating environment & 4 & 4 \\
\hline
\end{tabular}

Source: The researcher's data analysis

For most participants, encouragement and game incorporation are the two most effective ways to motivate students. Specifically, Mr. Thanh emphasized that this is the aspect he learned the most from Teaching Practicum. Given students' diffidence, he adopted the "demonstration approach" to make students realize that they could perform as well as him and frequently raised questions from a student's role. These "stimulated students to participate in activities" and "enlivened the atmosphere". He was "glad that this technique is currently applicable to FELTE students". Meanwhile, Ms. Linh alluded to curiosity and competitiveness as the most motivating factors. Based on this, she organized "games with scores", posed "life-related questions" or showed "videos to stimulate senses" to arouse enthusiasm. Another technique was the bonus point as stated by Ms. Trang:

I tend to use rewards to encourage responses from students. I usually add bonus points to the portfolio for those coming to the board, responding to my questions, or attending classes regularly.

These are the valuable experiences that they "learned from Teaching Practicum" (Ms. Trang). This enhancement in the creation of a motivating learning environment concurs with results from other empirical studies (Hobson et al., 2006; Scott. et al., 2014).

Another aspect of classroom management that came to the fore is an instructional skill, as found by previous research by Genç et al. (2016), Ralph (1994), and Scott et al. (2014). It is noticeable that most novice teachers chose rank 4 and the mean for this item is 3.59.

\section{Table 5}

Clearer and More Concise Instructions

\begin{tabular}{lcc}
\hline Benefits from Teaching Practicum & Mean & Mode \\
\hline Improved instructional skill & 3.59 & 4 \\
\hline
\end{tabular}

Source: The researcher's data analysis

In the interview, many novice teachers recounted that their instructions were "wordy and unclear to the students" because they lacked instructional skills. However, during Teaching Practicum they had the chance to practice in a real class to gradually make instructions more concise. Among all respondents, Ms. Thao emphatically regarded her instructional skills as one of three aspects she benefited the most from Teaching Practicum. Meanwhile, Ms. Linh adopted her supervisor's instructional style, which is "always giving detailed instructions about upcoming activities, commendable and blameworthy behavior". She explained that this vicarious experience resulted in her improvement in instructional skills. In short, many lecturers have improved on their initially lengthy and circuitous instructions by constant practicing during Teaching Practicum.

Some participants also mentioned the improvement in behavioral problem management skills as a benefit derived from Teaching Practicum. Most teachers agreed that their behavioral problem management skills have improved, as illustrated in mean values ranging from 3.35 to 4 and modes standing at 3 and 4. 


\section{Table 6}

Behavioral Problem Management

\begin{tabular}{|l|c|c|}
\hline \multicolumn{1}{|c|}{ Benefits from teaching practicum } & Mean & Mode \\
\hline Effective measures to deal with behavioral problems & 3.35 & 3 \\
\hline $\begin{array}{l}\text { Maturity and Calmness in reacting to unexpected student } \\
\text { behavior }\end{array}$ & 4 & 4 \\
\hline
\end{tabular}

Source: The researcher's data analysis

However, according to most novice lecturers, this behavioral problem management skill is not a worrying aspect as generally, FELTE students are "well-behaved". However, in some cases, such as students' sleeping, talking, or grunting, they need to resort to some techniques acquired during Teaching Practicum. The initial and most popular technique is "silent treatment" or "frowning". Ms. Mai emphasized that frowning made students realize "something is not right" and thus behaving more properly, which bore resemblance to Ms. Ngoc's case. Both participants were pleased that such methods are still applicable in their current situation. This finding is consistent with previous views (e.g., Dicke et al., 2015; O’Neill \& Stephenson, 2012).

\subsection{Problems and influencing factors related to Teaching Practicum}

Data from our study revealed that there are some restraining problems related to Teaching Practicum, as upheld by other research. Nevertheless, the results of this study also showed that some turned out to be factors which student teachers could utilize to improve their classroom management skills. This is a note-worthy and opposite point compared to the views of previous researchers.

It emerged from the interviews that school choice offered both benefits and drawbacks to novice teachers. On the one hand, practicing in the same educational context would give them a better understanding of the teaching environment. In this research, Ms. Mai, Ms. Thao, and Ms. Trang practiced teaching in FELTE. Not only did they find it beneficial in acknowledging the curriculum and philosophy but also in establishing relationships with lecturers and students. Interestingly, different environments also provided pre-service teachers with the chance for improvement. One noteworthy case is Ms. Ngoc who practiced in primary school. She shared that this seemingly irrelevant experience improved her ability to handle learners' behavior and maintain students' attention in her current classes. Similarly, Mr. Thanh also benefited from practicing in a different environment. Given students' reservation, what Mr. Thanh learned the most was "to motivate and inspire students to let them speak and enjoy activities", which explains his confidence in fostering a stimulating class atmosphere in FETLE. Notably, these benefits do not attest to Sulistiyo et al. (2017), which suggested that different environments resulted in irrelevant experience. Nevertheless, school choice presented certain difficulties. Ms. Quynh Anh believed that she should have chosen university because some of her experience was "not applicable" in her current situation due to the difference in students' characteristics and academic environment.

Furthermore, in contrast to previous studies (Kagan, 1992; Sulistiyo et al., 2017), some of our participants did not find the duration of Teaching Practicum inadequate. Most participants disagreed with the fact that there were too many tasks in such a short time (Mode $=2$ - Disagree) and the Teaching Practicum's duration was short (Mode $=3$ - Neutral). 


\section{Table 7}

Difficulties related to the timing of Teaching Practicum

\begin{tabular}{lcc}
\hline & Mean & Mode \\
\hline Short duration & 2.47 & 3 \\
Many tasks in such a short time & 2.41 & 2 \\
Juggling between Teaching Practicum and other learning tasks & 1.82 & 1 \\
\hline
\end{tabular}

Source: The researcher's data analysis

For example, Ms. Quynh Anh, Ms. Mai and, Ms. Linh stated that it was adequate for them to know the students well enough and to "teach and test their proficiency". On the other hand, Mr. Thanh and Ms. Ngoc concurred that it would be much better to extend Teaching Practicum for more experience acquisition. Moreover, in Ms. Ngoc's opinion, the Practicum should be divided into more separate periods for student teachers to revise the theory and method. These opinions are similar to the views of Sulistiyo et al. (2017) and Nguyen et al. (2009). Moreover, other lecturers encountered the problem of simultaneously juggling among heavy tasks, specifically undergoing Teaching Practicum and completing the thesis at the same time.

Concerning supervision, interviews revealed that supervisors were role models and providers of constructive comments as well as support for most participants. A careful analysis from the questionnaire data indicates that novice lecturers faced little difficulty with supervisors. This is evidenced by the mean values, which range from 1.59 to 1.89 and mode mostly at 1 (Strongly Disagree).

\section{Table 8}

Difficulties related to supervisors

\begin{tabular}{lcc}
\hline & Mean & Mode \\
\hline Difficulty in contacting your supervisor & 1.645 & 1 \\
Inadequate time to consult them & 1.76 & 1 \\
Little feedback about your practices & 1.71 & 1 \\
Inadequate guidance throughout the course & 1.89 & 1 \\
Less supervision than you expected & 1.82 & 2 \\
Lack of evaluation standards. & 1.88 & 1 \\
A sense of demotivation & 1.59 & 1 \\
\hline
\end{tabular}

Source: The researcher's data analysis

Supervisors' teaching or managing styles are worth learning. For instance, Ms. Mai admitted that she learned from her mentor in "setting clear and definitive rules right from the beginning of the lesson". More importantly, supervisors' meticulous feedback played an important role in enhancing participants' teaching style as Ms. Thao shared that: "My supervisor was very professional, very understanding and gave strict and constructive comments for me to really grow". This valuable feedback proved to be a common phenomenon among the majority of participants. Such results drew a remarkable distinction from previous findings claiming problems with supervisors in terms of communication and feedback (e.g., Genç, 2016; Sulistiyo et al., 2017). 
Nevertheless, there was only one case of Ms. Quynh Anh when her supervisor gave little feedback and supervision. She alluded to his disinterest in "giving feedback or helping me [her] with Teaching Practicum".

As can be seen, in general, supervisors played an important role in helping teacher trainees to improve their classroom management skills.

\section{Conclusion}

\subsection{Conclusion}

The results of this study suggested that Teaching Practicum generally had beneficial impacts on novice teachers' classroom management skills, especially in terms of attention-drawing and response encouragement; creation of a motivating environment as well as improved physical and emotional interaction with students. Concerning aim two, some significant drawbacks vis-àvis Teaching Practicum emerging from our research include learning course (ELT) and timing.

We also gathered some interesting points that run counter to some previous studies. Specifically, supervisors and school choice were not significant problems for novice teachers in Teaching Practicum. Nevertheless, such problems turned out to be influencing factors of which prospective teachers could take advantage.

Although the study was carried out in the context of one university only, the researchers hope that its results could provide a summary of potential gains in classroom management skills thanks to Teaching Practicum and keep the student teachers informed of some imminent difficulties during their Practicum.

\subsection{Limitations and suggestions for further studies}

Despite the best efforts made by the researchers, some limitations of this study need to be noted, namely low response rate or the intrinsic nature of self-report data, the possibility of inaccurate recall, and the impossibility to validate responses (O’Neill \& Stephenson, 2012).

Some following recommendations could be taken into consideration by the future researchers of this topic to make their research results more conclusive. Firstly, it is suggested that further research be conducted on a larger scale to enhance the generalizability of the results. Secondly, investigations into these skills of student teachers who did not enroll in Teaching Practicum would provide further juxtaposition, which leads to a more salient identification of the Teaching Practicum's impacts. Lastly, future studies could focus on a criteria-based evaluation of classroom management skills to gain more objective results. Such recommendations can make one further step on making the results of future studies into this field even more conclusive and reliable.

\section{References}

Andabai, P. (2013). The impact of teaching practice on trainee teachers in the Nigerian tertiary institutions: The Niger Delta university experience. Academic Journal of Interdisciplinary Studies, 2(5), 109-115. doi:10.5901/ajis.2013.v2n5p109

Beck, C., \& Kosnik, C. (2000). Associate teachers in preservice education: Clarifying and enhancing their role. Journal of Education for Teaching, 26(3), 207-224. doi:10.1080/713676888

Brenes-Carvajal, M. G. del C. (2009). Initial development of English language teachers in Mexico (Doctoral dissertation, Macquarie University, Sydney, Australia). 
Burman, E., \& Parker, I. (1993). Discourse analytic research: Repertoires and readings of texts in action. London, UK: Routledge.

Caires, S., Almeida, L., \& Vieira, D. (2012). Becoming a teacher: Student teachers' experiences and perceptions about teaching practice. European Journal of Teacher Education, 35(2), 163-178. doi:10.1080/02619768.2011.643395

Cerit, Y. (2011). The relationship between pre-service classroom teachers' self-efficacy beliefs and classroom management orientations. Buca Eğitim Fakültesi Dergisi, 30, 156-174.

Check, J., \& Schutt, R. K. (2011). Research methods in education. New York, NY: Sage Publications.

Dicke, T., Elling, J., Schmeck, A., \& Leutner, D. (2015). Reducing reality shock: The effects of classroom management skills training on beginning teachers. Teaching and Teacher Education, 48, 1-12. doi:10.1016/j.tate.2015.01.013

Edem, D. A. (2003). Introduction to educational administration in Nigeria. Onitsha, Nigeria: Leotina Nigeria Ltd.

Fanselow, J. F., \& Light, R. L. (1977). Bilingual, ESOL and foreign language teacher preparation: Models, practices, issues. Washington, D.C.: Teachers of English to Speakers of Other Languages.

Genç, Z. S. (2016). More practice for pre-Service teachers and more theory for in-service teachers of English language. Procedia - Social and Behavioral Sciences, 232, 677-683. doi:10.1016/j.sbspro.2016.10.092

Griffee, D. T. (2012). An introduction to second language research methods: Design and data. TESL-EJ Publications, Berkeley.

Griffin, C. (2004). The advantages and limitations of qualitative research in psychology and education. Scientific Annals of the Psychological Society of Northern Greece, 2(1), 3-15. doi:10.5539/jel.v6n1p102

Grudnoff, L. (2011). Rethinking the practicum: Limitations and possibilities. Asia-Pacific Journal of Teacher Education, 39(3), 223-234. doi:10.1080/1359866X.2011.588308

Harris, D. N., \& Sass, T. R. (2007). Teacher training, teacher quality, and student achievement. Journal of Public Economics, 95(7/8), 798-812. doi:10.1016/j.jpubeco.2010.11.009

Heppner, M. J. (1994). An empirical investigation of the effects of a teaching practicum on prospective faculty. Journal of Counseling \& Development, 72(5), 500-507. doi:10.1002/j.1556-6676.1994.tb00980.x

Hobson, A. J. (2006). Becoming a teacher: Student teachers experiences of initial teacher training in England. Nottingham, UK: Dept. for Education and Skills.

Jensen, B., Sandoval-Hernández, A., Knoll, S., \& Gonzalez, E. J. (2012). The experience of new teachers: Results from TALIS 2008. Paris, France: Organisation for Economic Co-operation and Development (OECD).

Kagan, D. M. (1992). Professional growth among preservice and beginning teachers. Review of Educational Research, 62(2), 129-169. doi:10.3102/00346543062002129

Kaur, P., \& Ranu, S. K. (2017). Classroom management in relation to professional commitment of secondary school teachers. Educational Quest- An International Journal of Education and Applied Social Sciences, 8(1), 193-199. doi:10.5958/2230-7311.2017.00029.0 
Khuc, T. N., \& Le, T. H. (2015). Pilot training to improve the classroom management skills of students at the Hanoi National University of Education. Journal of Science, Educational Science, 60(8B), 78-86. doi:10.18173/2354-1075.2015-0194

Macías, D. F., \& Sánchez, J. A. (2015). Classroom management: A persistent challenge for preservice foreign language teachers. PROFILE Issues in Teachers Professional Development, 17(2), 81-99. doi:10.15446/profile.v17n2.43641

Ngidi, D. P., \& Sibaya, P. T. (2003). Student teacher anxieties related to practice teaching. South African Journal of Education, 23(1), 18-22.

Nguyen, N. T. (2010). Nghiên cứu định tính về nhüng khó khăn của giáo sinh trong thời gian thưc tập su pham [Student teachers' self-reported challenges during the practicum (A Qualitative study)] (Master's thesis, University of Languages and International Studies, Vietnam National University, Hanoi). Retrieved March 8, 2020, from https://repository.vnu.edu.vn/handle/ VNU_123/40854

Nguyen, T. T., Nguyen, P. T., \& Do, P. T. (2009). Về thực tập sư phạm của sinh viên hệ sư phạm Trường Đại học Ngoại ngữ - Đại học Quốc gia Hà Nội [About the pedagogical practice of pedagogical students of the University of Foreign Languages - Hanoi National University]. Tạp chí Khoa hoc ĐHQGHN, Ngoại ngũu, 25(1), 51-56. Retrieved March 20, 2020, from https://js.vnu.edu.vn/FS/article/view/2234

O’Neill, S., \& Stephenson, J. (2012). Does classroom management coursework influence preservice teachers' perceived preparedness or confidence? Teaching and Teacher Education, 28(8), 1131-1143. doi:10.1016/j.tate.2012.06.008

Ozdemir, A. A., \& Yildirim, G. (2012). The effects of teaching practice course on professional development of student teachers. Procedia - Social and Behavioral Sciences, 46, 2550-2555. doi:10.1016/j.sbspro.2012.05.520

Perry, R. (2004). Teaching practice for early childhood. A guide for students. Retrieved March 7 , 2020, from http://wwwRoutledge.comcatalogues./0418114838.pdf

Pigge, F. L., \& Marso, R. N. (1990). A longitudinal assessment of the affective impact of preservice training on prospective teachers. The Journal of Experimental Education, 58(4), 283-289. doi:10.1080/00220973.1990.10806542

Ragawanti, D. T. (2015). Cultivating pre-service teachers' classroom management skills through teaching practicum: A reflective practice. TEFLIN Journal - A Publication on the Teaching and Learning of English, 26(1), 117-128. doi:10.15639/teflinjournal.v26i1/117-128

Rahman, F., Jumani, N. B., Akhter, Y., Chisthi, S. U. H., \& Ajmal, M. (2011). Relationship between training of teachers and effectiveness teaching. International Journal of Business and Social Science, 2(4), 150-160. Retrieved March 15, 2018, from http://ijbssnet.com/journals/Vol._2_No._4;_March_2011/18.pdf

Rahman, M. S. (2016). The advantages and disadvantages of using qualitative and quantitative approaches and methods in language "testing and assessment" research: A literature review. Journal of Education and Learning, 6(1), 102-112. doi:10.5539/jel.v6n1p102

Ralph, E. G. (1994). Beginning teachers as effective classroom managers. McGill Journal of Education/Revue des sciences de l'éducation de McGill, 29(2), 181-196. 
Ralph, E., Walker, K., \& Wimmer, R. (2007). The Practicum in professional education: Pre-service students' experiences. Transformative Dialogues: Teaching \& Learning Journal, 1(2), 1-17. Retrieved March 10, 2020, from https://www.kpu.ca/sites/default/files/Teaching and Learning/ TD.1.2_Ralph_Practicum_Professional_Education.pdf

Richards, J. C., \& Farrell, T. S. (2013). Practice teaching: A reflective approach. New York, NY: Cambridge University Press.

Romi, S., \& Leyser, Y. (2006). Exploring inclusion preservice training needs: A study of variables associated with attitudes and self-efficacy beliefs. European Journal of Special Needs Education, 21(1), 85-105. doi:10.1080/08856250500491880

Scott, L. A., Roberta, G., \& Melissa, P. (2014). Making preservice teachers better: Examining the impact of a practicum in a teacher preparation program. Educational Research and Reviews, 9(10), 294-301. doi:10.5897/err2014.1748

Sivri, H., \& Balc1, E. (2015). Pre-service teachers' classroom management selfefficacy beliefs. International Online Journal of Educational Sciences, 7(4), 37-50. doi:10.15345/iojes.2015.04.004

Sulistiyo, U., Mukminin, A., Abdurrahman, K., \& Haryanto, E. (2017). Learning to teach: A case study of student teachers' practicum and policy recommendations. The Qualitative Report, 22(3), 712-731. Retrieved March 11, 2020, from http://nsuworks.nova.edu/tqr/vol22/iss3/3

Tan, O. S., Parsons, R. D., Hinson, S. L., \& Sardo-Brown, D. (2003). Educational psychology: A practitioner-researcher approach. Australia: Thomson.

Tarman, B. (2012). Prospective teachers beliefs and perceptions about teaching as a profession. Educational Sciences: Theory \& Practice, 12(3), 1964-1973.

Tschannen-Moran, M., Hoy, A. W., \& Hoy, W. K. (1998). Teacher efficacy: Its meaning and measure. Review of Educational Research, 68(2), 202-248. doi:10.2307/1170754

University of Languages and International Studies, Vietnam National University, Hanoi. (2013). 1403 - Quy chế thưc tập su phạm [1403 - The Regulation on pedagogical practice]. Retrieved November 28, 2017, from http://daotao.ulis.vnu.edu.vn/files/uploads/2017/12/0.1403-Quy-che-TTSP-gray.pdf

Wagenaar, M. (2005). Student teachers' experiences of practice teaching (Master's thesis, University of Zululand, Kwa Dlangezwa). Retrieved March 12, 2020, from http://uzspace.uzulu.ac.za/

bitstream/handle/10530/523/Student\%20teachers\%20experiences.\%20M.\%20Wagenaar.pd f? sequence $=1$

Zeichner, K. (1996). Designing educative practicum experiences for prospective teachers. In K. Zeichner, S. Melnick \& M. L. Gomez (Eds.), Currents of reform in preservice teacher education (pp. 215-234). New York, NY: Teachers College Press. 